\title{
NOG EENS DE BOVENWINDSCHE EILANDEN \\ DOOR
}

Mejuffrouw L. SLOTHOUWER.

In den laatsten tijd is langzaam, maar zeker Holland's belangstelling gewekt voor deze drie vergeten stipjes in de Caraïbische Zee, waar toch ook de Hollandsche driekleur haar helder Rood, Wit en Blauw doet wapperen op den warmen tropenwind. In Curaçao heeft de Heer Beaujon een goed werk gedaan door in den Kolonialen Raad een pleidooi te houden voor deze eilanden, behoorend tot het gebiedsdeel Curaçao, hoewel dit hem niet veel gegeven heeft, daar op de begrooting 1930 geen extra posten voor de Bovenwinden zijn uitgetrokken.

Maar er moet meer komen dan belangstelling; die belangstelling moet omgezet worden in daden!

Heel gemakkelijk valt het te zeggen: „De Bovenwinden verkeeren in zulk een toestand van verval, dat het niet de moeite loont, er geld aan te besteden. Laat ze maar langzaam doodbloeden". Zal een moeder met een zwak, ziekelijk stumperdje van een kind verzuimen de hulp in te roepen van een dokter, omdat de maatschappij geen behoefte heeft aan dit zielige kindje? Is niet juist dit kind haar liefste schat?

Zal een dokter een patiënt in den steek laten, omdat deze ten doode is opgeschreven? Doet hij niet zijn uiterste best de smeulende levensvonk zoo lang mogelijk gloeiend te houden?

En onze mooie Bovenwinden liggen daar, lamgeslagen door de emigratie. En geen hulp zal baten, zoo lang niet de Bovenwinder terugkeeren kan. Niet uit verkiezing is deze een blijvende emigrant. Talloos zijn de gevallen, dat zij, die reeds jaren in den vreemde werken, hun spaarpen- 
ningen gebruiken om op hun geboorte-eiland een huisje en een plekje grond te koopen, om er later in rust en kalmte te gaan leven, terwijl alles culmineert in het verlangen te midden van hun landgenooten te sterven. 't Nieuwe, 't onbekende moge hem lokken, de hoop op hooge loonen hem tot emigreeren bewegen, zijn hart trekt hem steeds weer naar zijn ,dear old home”.

Maar niet alleen bestaansvoorwaarden moeten hem geboden worden, hij moet ook iets vinden, dat hem schadeloos zal stellen voor het gemis van het woelige, drukke leven op Curaçao met zijn bioscopen en danshuizen. De Bovenwinder is een groot, eenvoudig kind en deze kinderhand is al heel gauw gevuld.

De krachten, op de eilanden achtergebleven, hoewel in vele opzichten minderwaardig, zijn zich van hun waarde bewust en eischen een zware betaling, als zij tenminste nog tot werken te krijgen zijn, want, zoolang zij nog één dollar in den zak hebben, gaan ze liever dobbelen en trekken pas weer aan den arbeid, als geldgebrek er hen toe dwingt.

Ter vergelijking een lijstje van werkloonen, uitbetaald in Mei 1929 op het katoen-eiland Montserrat, waar voldoende arbeiders zijn en een van St. Martin in dezelfde maand:

Montserrat

timmerlieden: . . . . $f 2,25$

ploegers: . . . . . . $f 0,90$

hoofd. karrenleiders: . $f 0,80$

gew. karrenleiders: . . $f 0,70$

veldarbeiders: . . . $f 0,70$
St. Martin

$f$ 5.- tot $f$ 6.$f 2,50$

$f 1,50$ tot $f 2$. $f 0,75$ tot $f 1$. - . $f 1,25$ tot $f 1.35$.

Wat betreft het rapen van zout, betaalt Anguilla per barrel (1,05 H.L. of \pm 124 K.G.) slechts 20 cts, terwijl aan de rapers op St. Martin $f$ 0,37 per barrel betaald moet worden.

\section{Zoutindustrie.}

Den laatsten tijd is er heel veel geschreven, heel veel gesproken en heel veel gemopperd over de zoutindustrie op St. Martin en in veel dier gevallen krijgen de exploi- 
tanten de schuld, daar zij volgens deskundigen niet met hun tijd meegaan, (zie o.a. het artikel van den Heer F. S. Langemeijer C. I. Het Zoutbedrijf op St. Martin. Een onderzoek naar de middelen te zijner verbetering, in de West Indische Gids van September en October 1921). Volgens die deskundigen wordt het geheele bedrijf nog voortgezet op dezelfde wijze als vijftig jaar geleden en wordt de geheele moderne tijd met zijn nieuwste ontdekkingen en uitvindingen totaal geïgnoreerd.

Toegegeven, want waar deskundigen spreken, hoort de leek te zwijgen, maar een ouderwetsche methode is daarom nog niet altijd een slechte methode! En dan, hoe staan de exploitanten er voor?

De houders der concessies van de St. Martijnsche zoutpannen hebben het ontginnen ervan in handen gegeven van een exploitatiemaatschappij; deze concessies loopen tot 1939. De exploitanten zijn er dus nu volstrekt niet zeker van, dat zij ook na dien tijd met de exploitatie kunnen voortgaan. Dit vooruitzicht werkt nu juist niet het in gebruik stellen van dure werktuigen in de hand. En dan, als er geen winst wordt gemaakt, waar moet dan het geld vandaan komen voor het aanschaffen van die moderne middelen?

Enschuilt werkelijk de fout van dit niet-rendeeren in de ouderwetsche methode of zijn er misschien andere oorzaken aan te wijzen?

Tot voor kort vond het St. Martijnsche zout een afzetgebied in:

Suriname

Porto-Rico en de Vereenigde Staten van N.-Amerika.

Canada

de Engelsche Westindische Eilanden

de Fransche Westindische Eilanden.

Wat Suriname betreft, moet St. Martin concurreeren met Bonaire en Curaçao, die zooveel dichter bij liggen.

Voor Porto Rico, de Vereenigde Staten en Canada is er concurrentie met Bonaire, Anguilla en Turks' Island.

Voor de Engelsche en Fransche Antillen moet er geconcurreerd worden met Anguilla. 
Gedurende het tijdvak 1 Juli 1928 tot 1 Juli 1929 werd op St. Martin

geoogst . . . . . . . . . . $28633 \frac{1}{2}$ barrel

verkocht .. . . . . . . . $12932 \frac{1}{2}$ barrel

over . . . . . . . . . . . $\overline{15701}$ barrel,

't Raaploon bedroeg voor die $28633 \frac{1}{2}$ barrel $f$ 10598,49 wat dus voor de verkochte $12932 \frac{1}{2}$ barrel maakte

$\frac{12932 \frac{1}{2}}{28633 \frac{1}{2}} \times f 10598,49=f 4786,87$ of $f 0,37140$ per barrel verschepingskosten

totaal: $f 0,59514$ per barrel.

Hierbij zijn dan uitgeschakeld, andere onkosten, zooals commissieloon, uitvoerrechten, enz. die den totalen kostenden prijs opvoeren tot $f 0,94$.

Voor Anguilla bedroeg dit:

raaploon .. . . . . . . . . . . . . $f 0,20$

verschepingskosten. . . . . . . . . . . $\frac{. f 0,12 \frac{1}{2}}{\text { totaal }} \frac{.}{f 0,32 \frac{1}{2}}$

't Anguilla-zout kan dus, alleen reeds door voldoende arbeidskrachten een voordeel behalen van $f 0,59 \frac{1}{2}-$ $f 0,32 \frac{1}{2}=f 0,27$ per barrel.

Hierdoor worden dus van de markt voor St. Martin uitgesloten: Suriname, Porto Rico en de Vereenigde Staten, de Fransche Antillen.

Om het Engelsche zout te beschermen, wordt er op de Engelsche Antillen, de Bahamas, de Bermudas en in Canada slechts $f 2,40$ per ton of $f 0,30$ per barrel aan invoerrechten geheven, terwijl deze invoerrechten voor vreemd, dus ook voor St. Martijnsch zout $f$ 4,80 per ton of 0,60 per barrel bedragen.

Concurrentie met Anguilla op de Engelsche eilanden en in Canada is dus uitgesloten, niet alleen wat betreft de hoogere zoutprijzen, maar eveneens door de 't Anguillazout beschermende invoerrechten.

Turks' Island verkoopt meestal gemalen zout en wel tegen $f$ 0,90 per barrel, terwijl de kostende prijs voor ge- 
malen zout op St. Martin reeds komt op $f$ 0, 94 en nog $f 0,25$ maalloon of op $f 1,19$ per barrel.

De rapers verdienen in de St. Martijnsche zoutpannen van $f 4,25$ tot $f$ 4,50 per dag. Hiervan betalen zij, zoo zij het zout niet zelf naar den zouthoop willen dragen, maar dit door vrouwen laten doen, aan elke vrouw $f 1$. - .

Vroeger verdienden de rapers $f 0,15$ per barrel, nu $f 0,37$

Vroeger werden er 3000 tot 4000 barrels per dag geraapt, nu is dit \pm 190 barrel per dag.

Vroeger rapers te kust en te keur! Nu is het mooi, als er 3 captains in de pannen gaan, elk met een crew van 3-5 menschen.

Katoen.

Door de hooge dagloonen staat ook de verbouw van katoen stil.

Wat heeft men daarentegen op de Engelsche eilanden gedaan om de ook daar dreigende emigratie tegen te gaan, want de hooge loonen op Curaçao beloofden niet alleen onzen Bovenwinders gouden bergen.

Op Montserrat, thans een welvarend katoen-eiland, werden van Gouvernementswege de arme planters in staat gesteld, katoen te blijven planten, toen dit eiland, tengevolge van de daling der prijzen, met ondergang werd bedreigd.

Op Dominica en Antigua wordt de lemoen-cultuur krachtig gesteund.

Op Anguilla het zout.

Op Nevis en St. Kitts de suikerriet-teelt.

Op de Virgin-eilanden eveneens, benevens de tabakscultuur.

Overal komt het Gouvernement, finantiëel steunend, de eilanden te hulp en landbouwkundigen worden aangesteld om zoowel den grooten als den kleinen planter van raad en voorlichting te dienen. Zoo wordt hier overal de kleine man, de backbone der economische welvaart, gesteund.

Op onze Bovenwindsche Eilanden is echter niet alleen finantiëele en technische hulp noodig, ook het product 
moet beschermd worden. De katoen van $\mathrm{St}$. Eustatius en St. Martin toch heeft haar goeden naam verioren, doordat de mooie, lange, zijdeachtige Sea-islanddraad vermengd werd met kortdradige, dus minderwaardige katoen.

$\mathrm{Nu}$ komt het vaak voor, dat de planter zijn eigen katoen, zijn eigen groenten, zijn eigen vruchten moet koopen van hen, die het gestolen hebben.

\section{Veestapel.}

De veestapel is vrij goed, doch er is aanvoer van nieuw stamvee van het Maas-, Rijn- en IJselveeslag noodig. Ongeveer acht jaar geleden werden door de goede zorgen van den toenmaligen landbouwkundige, den Heer Van der Plaats, ingevoerd twee stieren en drie vaarzen, waarvan nog één stier en één koe over zijn, n.l. Jan 5, stamboeknummer 18716 en Prinses, stamboeknummer 14637.

Om den veestapel op peil te houden, zou het nu in de eerste plaats wenschelijk zijn, een jongen stier in te voeren, die noch met Jan 5, noch met Prinses verwant is. Een roodbonte stier van het Maas- Rijn- en IJselslag, roodbont, vooral op den rug, daar de brandende zonnestralen op een witten rug spoedig blaren trekken.

Ook aan de geiten, deze koe der armen, is nieuw en goed bloed toegevoerd, doordat een paar particulieren exemplaren van het Schotsche en 't Hollandsche ras hebben ingevoerd.

Delfstoffen.

St. Martin heeft zeer veel manganese. Reeds waren twee Amerikaansche firma's, die zeer ingenomen waren met de gezonden inlichtingen en monsters, bereid, deze manganese te gaan ontginnen, maar het wachten was op de tariefherziening. Deze is echter tegengevallen en daarmee zal wel de kans verkeken zijn op dezen uitvoer.

Ook met de zwavelmijnen op Saba was iets dergelijks het geval. De mijnen zijn rijk, de zwavel is mooi, maar het vervoer naar de kust en het verschepen stuit op veel moeilijkheden en zal daardoor veel geld verslinden om het vervoeren mogelijk te maken.

Hoewel het aan den eenen kant een verblijdend feit zou 
zijn, zoo Amerikaansche firma's tot de ontginning èn van manganese èn van zwavel besloten, zoo zouden toch de winsten niet blijvend de eilanden ten goede komen, maar naar Amerika wegvloeien. Nu blijft de hoop, dat Hollandsche ondernemingsgeest en Hollandsch kapitaal deze bronnen van inkomsten voor onze Bovenwinders zullen openen.

\section{Sanatorium.}

Saba met zijn mooie natuur en koel, zenuwsterkend klimaat is een ideaal oord om er een sanatorium op te richten voor rustbehoevenden uit den geheelen Antillen-archipel. Hier geen radio's, geen schetterende automobielhoorns, geen enerveerend geklingel van fietsbellen, geen zenuwachtig uitkijken van den voetganger om te zien of hij veilig de overzijde kan bereiken, hier geen schreeuwen en gillen van inlanders, hier geen lucht, bezwangerd met stof en walm, maar rust, weldadige rust en kalmte en koele, zuivere, van zon doortrokken lucht. Maar . . wil hier een sanatorium bloeien, dan moet men het eiland gemakkelijk en vlug kunnen bereiken, zonder zeeziekte als voor- en nagerecht.

\section{Belastingen.}

Velen zijn voor de afschaffing der belastingen, daar zij hierin een middel zien om de eilanden te helpen en waardoor industrieëlen en anderen aangelokt zullen worden een of ander werk op deze eilanden te beginnen. Anderen daarentegen en dezen vormen de groote meerderheid der bevolking, beschouwen deze afschaffing als een degradatie voor de inwoners, vooral, daar niets door hen op prijs gesteld wordt, wat zoo gemakkelijk verkregen wordt, hoogstens willen zij het drankaccijns zien verdwijnen, daar door de smokkelarij op groote schaal en die toch onmogelijk tegen te gaan is, deze belasting slechts op enkelen drukt. Er tegenover staat, dat dan de kwijnende handel met St. Thomas en Porto Rico, kwijnend door den geringen omzet, geheel zal stilstaan.

Maar daar Curaçao in zijn tegenwoordigen bloei deze gelden niet noodig heeft, zou misschien de oplossing van 
beide meeningen in het midden kunnen liggen en wel, dat het Gouvernement voortgaat belastingen te heffen, doch dit geld kome geheel ten goede aan zaken van algemeen belang op de eilanden, zooals het onderhoud van wegen, bruggen, gebouwen, het bouwen van regenbakken, het graven van artesische putten, het uitdiepen van wellen en crabholes, enz. terwijl landbouw, veeteelt en andere bestaansmiddelen door voorschotten in staat worden gesteld, zich uit hun treurigen toestand op te heffen.

\section{Samenwerking}

Maar noch Curaçao, noch Holland zelfs, kunnen deze eilanden tot een wederopbloei van economische welvaart brengen, als niet de Bovenwinders zelf medewerken. Medewerken, niet alleen door al hun krachten in te spannen, maar, en dit vooral, door samen te werken.

Vergeten moeten worden groote en kleine grieven, groote en kleine geschillen tusschen de menschen van één eiland, tusschen de menschen van de eilanden onderling, Alles, wat nu verdeelt, moet terzijde gesteld worden om samen te streven naar één groot, gemeenschappelijk doel, opheffing der eilanden, die toch aan allen dierbaar zijn.

Onderlinge naijver verzwakt, getuige het volgende voorbeeld:

St. Martin stelt op Curaçao een agent aan, die zich belasten zal met den verkoop van de artikelen, uit St. Martin aangevoerd en daarvoor 5\% commissieloon vraagt. $\mathrm{Om}$ de een of andere reden draagt deze agent niet de goedkeuring weg van de Statianen, die een anderen agent nemen, die echter 10\% vraagt. Enfin, dit is in hun eigen nadeel. Maar wat is het gevolg? Een onderkruipen van elkaars prijzen, waarbij de kooper wel vaart, doch waarbij de verkooper zich in zijn winst belangrijk geschaad ziet.

Zeker geldt voor deze eilanden het woord, dat het oude Holland groot maakte:

Eendracht maakt macht, Tweedracht breekt kracht. 